\title{
Behavior of Natural Estrogens in Activated Sludge: Biodegradation in Semicontinuous Reactor under Aerobic, Anaerobic and Sequential Anaerobic/Aerobic Conditions
}

\author{
Reni Desmiarti ${ }^{1,2}$ \& Fusheng $\mathrm{Li}^{3}$ \\ ${ }^{1}$ Department of Chemical Engineering, Bung Hatta University, \\ Jalan Olo Nanggalo No. 19 Padang 25137, Indonesia \\ ${ }^{2}$ Environmental Research Center, Bung Hatta University, \\ Jalan Olo Nanggalo No. 19 Padang 25137, Indonesia \\ ${ }^{3}$ River Basin Research Center, Gifu University \\ 1-1 Yanagido, Gifu 501-1193, Japan \\ E-mail: desmiarti@yahoo.com
}

\begin{abstract}
The behavior of natural estrogens was examined by separately spiking $17 \beta$-estradiol (E2) and estrone (E1) into semicontinuous activated sludge reactors operated under aerobic, anaerobic and sequential anaerobic/aerobic conditions. Under aerobic and anaerobic conditions, E1 was formed from E2. The conversion of E1 to E2 was did not occur under aerobic conditions. The maximum conversion of E2 to E1 was higher than the maximum conversion of E1 to E2. Overall, the degradation rate of E2 $\left(k_{\mathrm{E} 2}\right)$ was much faster than that of $\mathrm{E} 1\left(k_{\mathrm{E} 1}\right)$. The findings suggest that E1 is probably more persistent than E2 in effluent of sewage treatment plants.
\end{abstract}

Keywords: activated sludge; biodegradation; estrogens; estradiol; estrone.

\section{$1 \quad$ Introduction}

Natural estrogens such as estrone (E1), 17ß-estradiol (E2) and estriol (E3) are among the main environmental contaminants. The adverse effects of natural estrogens on aquatic organisms have been found in vitellogenesis [1], and feminization of male fish in British rivers [2]. Another study, Imai, et al. [3], has demonstrated that exposure to E2 (>16 $\left.\mathrm{n} \mathrm{L} \mathrm{L}^{-1}\right)$ affected the reproduction of marine male fishes. People, livestock and wildlife are the sources of natural estrogens in the water environment. The daily excretion of natural estrogens from males and females has been investigated by Johnson, et al. [4].

Natural estrogens have been detected in the effluent of sewage treatment plants (STP) in a range of 10-100 ng/L and their removal efficiency is in the range of $62-98 \%$ for E2 and $19-98 \%$ for E1 [5-7]. They have also been detected in rivers and lakes [8,9]. The behavior of natural estrogens in natural water environmental systems under aerobic and anaerobic conditions has been investigated by Desmiarti, et al. $[10,11]$.

Received January $1^{\text {st }}, 2013$, Revised March $12^{\text {th }}, 2013$, Accepted for publication March $28^{\text {th }}, 2013$.

Copyright () 2013 Published by ITB Journal Publisher, ISSN: 2337-5779, DOI: 10.5614/j.eng.technol.sci.2013.45.2.1 
$\mathrm{Li}$, et al. [12] have investigated the behavior of $\mathrm{E} 2$ in batch experiments using activated sludge from STP in Japan. They found that E2 was converted quickly to E1, and the degradation of E1 to unknown products was slower than that of E2. The presence of E2 and E1 in rivers and lakes implies that E2 and E1 are not completely removed by wastewater treatment plants. Hence, optimization of treatment processes and conditions is very important. $\mathrm{Li}$, et al. [13] have also investigated the behavior of natural estrogens in semicontinuous activated sludge under aerobic conditions. They found that E2 and E1 levels dropped rapidly due to sorption onto activated sludge, followed by biodegradation through microorganisms. However, under anaerobic conditions, E2 and E1 degradation was limited [14] and was not observed under sequential anaerobic/aerobic conditions. In order to understand the behavior of natural estrogens in real sewage treatment plants, it is very important to study the behavior of natural estrogens under sequential anaerobic/aerobic conditions.

The aim of this research was to study the behavior of E2 and E1 in an activated sludge sewage treatment plant. The semicontinuous experiments were carried out under aerobic, anaerobic and sequential anaerobic/aerobic conditions by spiking E2 or E1 separately into activated sludge liquor.

\section{Materials and Methods}

\subsection{Activated Sludge}

Activated sludge was collected from a sewage treatment plant (STP) in Gifu, Japan. This plant is operated in a sequential anaerobic/aerobic mode with a total hydraulic retention time (HRT) of $6 \mathrm{~h}$ in the bioreactor. Detailed information about activated sludge sampling is available in $\mathrm{Li}$, et al. [13]. The characteristics of the activated sludge liquor such as dissolved organic carbon (DOC), $\mathrm{pH}$, mixed liquor suspended solids (MLSS), mixed liquor volatile suspended solids (MLVSS) are displayed in Table 1. After sampling, the activated sludge liquor (about $60 \mathrm{~L}$ ) was quickly transported to the laboratory of Gifu University and separated into six reactors after weighting for experimental use.

Table 1 Characteristics of activated sludge liquor.

\begin{tabular}{ccc}
\hline Parameters & Unit & Value \\
\hline DOC & $\mathrm{mg} \mathrm{L}^{-1}$ & 17.32 \\
pH & & 6.64 \\
MLSS & $\mathrm{mg} \mathrm{L}^{-1}$ & 1081 \\
MLVSS & $\mathrm{mg} \mathrm{L}^{-1}$ & 973 \\
E2 & $\mathrm{ng} \mathrm{L}^{-1}$ & Not detected \\
E1 & $\mathrm{ng} \mathrm{L}^{-1}$ & Not detected \\
\hline
\end{tabular}




\subsection{Stock Solution of E2 and E1}

E2 and E1 are hydrophobic compounds. The Octanol/water partition coefficient $\left(\log \mathrm{K}_{\mathrm{ow}}\right)$ of E1 (2.45-3.43) is lower than that of E2 (3.94-4.01). This result indicates that E1 is more hydrophobic than E2 [15,16]. In previous studies, Urase and Kikuta [17] used acetone, and Auriol, et al. [15] used methanol, as the solvent for dissolving the natural estrogens in order to ensure that these were completely dissolved. For these experiments, the stock solutions of E2 and E1 were made by dissolving weighted amounts of E2 and E1 in methanol (Wako Pure Chemical Co., Osaka, Japan). The concentration of the stock solutions of $\mathrm{E} 2$ and E1 was $250 \mu \mathrm{g} \mathrm{L}{ }^{-1}$ for each. Methanol was controlled at a lower level in the reactors (about $0.012 \%$ as $\mathrm{v} / \mathrm{v}$ ).

\subsection{Experiments}

Two series of semicontinuous experiments were performed under aerobic, anaerobic and sequential anaerobic/aerobic conditions, spiking E2 or E1 into the reactor. The first series (Run 1 - Run 9) was used to study the behavior of E2, while the second series (Run 10 - Run 18) was used for investigating the behavior of E1. A glass bottle with a storage volume of $10 \mathrm{~L}$ was used as the reactor. The volume of the activated sludge liquor in the reactor was $8 \mathrm{~L}$. A schematic diagram of the experimental set-up is displayed in Figure 1. Under aerobic conditions, oxygen was continuously supplied to the reactor via an air diffuser (Figure 1(a)). Under anaerobic conditions, wetted nitrogen was consistently supplied through a diffuser (Figure 1(b)). In Figure 1(c), the experiment using the sequential anaerobic/aerobic mode was studied in the reactor, with a total hydraulic retention time (HRT) of $8 \mathrm{~h}$. The initial $3 \mathrm{~h}$ were assigned for the anaerobic reaction, where aeration was not conducted for enhanced removal of phosphorus. This was followed by $5 \mathrm{~h}$ of aerobic process achieved by continuous air supply. E2 or E1 were spiked into the reactors once a day for three consecutive days by adding stock solutions of E2 or E1 to provide initial E2 and E1 concentrations of $30 \mu \mathrm{g} \mathrm{L}{ }^{-1}$. For all experimental runs, $\mathrm{pH}$ was monitored continuously and adjustments were made when necessary with sodium hydroxide to maintain the liquor $\mathrm{pH}$ at around 6.7, i.e. the $\mathrm{pH}$ level of the activated sludge liquor sampled from the STP. As shown in Table 2, the changes in MLSS and MLVSS were relatively small. Correction by concentrating the mixed liquor within each reactor was not performed. In addition, we added ammonium chloride and potassium dihydrogen-phosphate as well, in order to provide an initial C:N:P ratio of 100:12.3:3.6.

Initially, E2 and E1 levels decreased rapidly [13]. To ensure data that could better describe the behavior of E2 and E1 in each reactor, the time intervals for sampling were carefully designed in order to obtain more data over the initial 
running periods. For each sampling, $10 \mathrm{ml}$ of the activated sludge liquor was put into a $10 \mathrm{ml}$ centrifuge tube and centrifugation was carried out immediately at $3500 \mathrm{rpm}$ for $1 \mathrm{~min}$. Then, following prompt filtration of the supernatant through a prewashed $0.45 \mu \mathrm{m}$ PTFE membrane filter (Toyo Roshi, Japan), the obtained filtrate was stored below $5^{\circ} \mathrm{C}$ before being subjected to analysis.

Table 2 Semicontinuous batch experimental conditions and observed variations in MLSS, MLVSS, $\mathrm{pH}$ and DO over the entire running period.

\begin{tabular}{|c|c|c|c|c|c|c|c|c|c|}
\hline \multicolumn{10}{|c|}{ Series I: Spiking of 17 $\beta$-estradiol (E2) } \\
\hline Conditions & \multicolumn{3}{|c|}{ Aerobic } & \multicolumn{3}{|c|}{ Anaerobic } & \multicolumn{3}{|c|}{$\begin{array}{c}\text { Sequential anaerobic } \\
(3 \mathrm{~h}) / \text { aerobic }(5 \mathrm{~h})\end{array}$} \\
\hline E2 conc. $\left(\mu \mathrm{g} \mathrm{L}^{-1}\right)$ & 30 & & & 30 & & & 30 & & \\
\hline Number of runs & $\begin{array}{l}\text { Run } \\
1\end{array}$ & $\begin{array}{l}\text { Run } \\
2\end{array}$ & Run 3 & Run 4 & $\begin{array}{l}\text { Run } \\
5\end{array}$ & Run 6 & Run 7 & Run 8 & $\begin{array}{l}\text { Run } \\
9\end{array}$ \\
\hline Spiking time (day) & $1^{\text {st }}$ & $2^{\text {nd }}$ & $3^{\text {rd }}$ & $1^{\mathrm{st}}$ & $2^{\text {nd }}$ & $3^{\text {rd }}$ & $1^{\mathrm{st}}$ & $2^{\text {nd }}$ & $3^{\text {rd }}$ \\
\hline $\operatorname{MLSS}\left(\mathrm{mg} \mathrm{L}^{-1}\right)$ & \multicolumn{3}{|c|}{$1113 \pm 29$} & \multicolumn{3}{|c|}{$1104 \pm 15$} & \multicolumn{3}{|c|}{$1060 \pm 22$} \\
\hline $\operatorname{MLVSS}\left(\mathrm{mg} \mathrm{L}^{-1}\right)$ & \multicolumn{3}{|c|}{$158 \pm 25$} & \multicolumn{3}{|c|}{$142 \pm 20$} & \multicolumn{3}{|c|}{$142 \pm 14$} \\
\hline $\mathrm{pH}$ & \multicolumn{3}{|c|}{$6.49 \pm 0.34$} & \multicolumn{3}{|c|}{$8.07 \pm 0.69$} & \multicolumn{3}{|c|}{$7.21 \pm 0.79$} \\
\hline $\mathrm{DO}\left(\mathrm{mg} \mathrm{L}^{-1}\right)$ & \multicolumn{3}{|c|}{$8.93 \pm 0.37$} & \multicolumn{3}{|c|}{$0.25 \pm 0.05$} & \multicolumn{3}{|c|}{$\begin{array}{l}0.38 \pm 0.07 \text { (Anaerobic) } \\
8.75 \pm 0.51 \text { (Aerobic) }\end{array}$} \\
\hline \multicolumn{10}{|c|}{ Series II: Spiking of estrone (E1) } \\
\hline Conditions & \multicolumn{3}{|c|}{ Aerobic } & \multicolumn{3}{|c|}{ Anaerobic } & \multicolumn{3}{|c|}{$\begin{array}{c}\text { Sequential anaerobic } \\
(3 \mathrm{~h}) / \text { aerobic }(5 \mathrm{~h})\end{array}$} \\
\hline E1 conc. $\left(\mu \mathrm{g} \mathrm{L}^{-1}\right)$ & 30 & & & 30 & & & 30 & & \\
\hline \multirow[t]{2}{*}{ Number of runs } & Run & Run & Run & Run & Run & Run & Run & Run & Run \\
\hline & 10 & 11 & 12 & 13 & 14 & 15 & 16 & 17 & 18 \\
\hline Spiking time (day) & $1^{\text {st }}$ & $2^{\text {nd }}$ & $3^{\text {rd }}$ & $1^{\mathrm{st}}$ & $2^{\text {nd }}$ & $3^{\text {rd }}$ & $1^{\mathrm{st}}$ & $2^{\text {nd }}$ & $3^{\text {rd }}$ \\
\hline $\operatorname{MLSS}\left(\mathrm{mg} \mathrm{L}^{-1}\right)$ & \multicolumn{3}{|c|}{$1160 \pm 65$} & \multicolumn{3}{|c|}{$1137 \pm 56$} & \multicolumn{3}{|c|}{$1070 \pm 15$} \\
\hline MLVSS (mg L $\left.{ }^{-1}\right)$ & \multicolumn{3}{|c|}{$164 \pm 26$} & \multicolumn{3}{|c|}{$138 \pm 22$} & \multicolumn{3}{|c|}{$146 \pm 23$} \\
\hline $\mathrm{pH}$ & \multicolumn{3}{|c|}{$6.44 \pm 0.33$} & \multicolumn{3}{|c|}{$8.1 \pm 0.7$} & \multicolumn{3}{|c|}{$7.2 \pm 0.7$} \\
\hline $\mathrm{DO}\left(\mathrm{mg} \mathrm{L}^{-1}\right)$ & \multicolumn{3}{|c|}{$9.05 \pm 0.4$} & \multicolumn{3}{|c|}{$0.2 \pm 0.08$} & \multicolumn{3}{|c|}{$\begin{array}{l}0.39 \pm 0.11 \text { (Anaerobic) } \\
8.78 \pm 0.32 \text { (Aerobic) }\end{array}$} \\
\hline
\end{tabular}

\subsection{The Apparent Degradation Rate}

The apparent degradation rates of E2 or E1 when spiked separately were generated by assuming a first-order reaction, described as follows:

$$
\frac{\mathrm{dC}}{\mathrm{dt}}=-k \mathrm{C}
$$

where $\mathrm{C}$ is the concentration of $\mathrm{E} 2$ or $\mathrm{E} 1\left(\mu \mathrm{gL} \mathrm{L}^{-1}\right), \mathrm{t}$ is time (h) and $k$ is the apparent first-order degradation rate constant $\left(\mathrm{h}^{-1}\right)$. The $k$ was approximated by fitting the experimental plots, $\ln \left(\mathrm{C} / \mathrm{C}_{0}\right)$ versus $\mathrm{t}$, with the following rewritten linear format: 


$$
\ln \frac{\mathrm{C}}{\mathrm{C}_{0}}=-k \mathrm{t}
$$

$\mathrm{C}_{0}$ is the initial concentration of E2 or E1 involved directly in the assumed firstorder rate reactions.
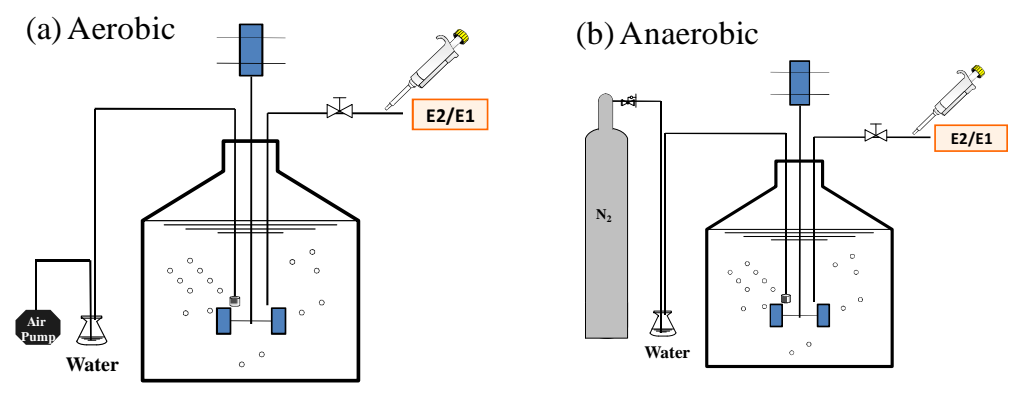

(c) Sequential Anaerobic/Aerobic
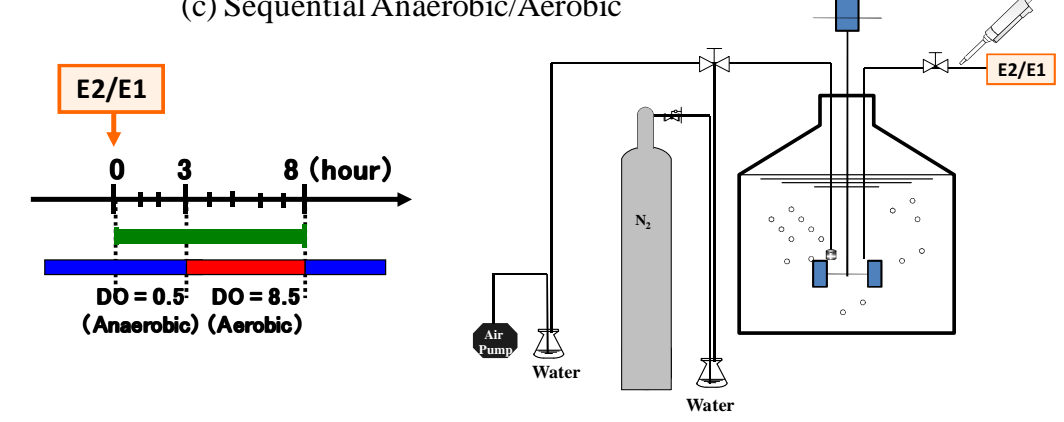

Figure 1 Schematic diagram of semicontinuous experiments under (a) aerobic, (b) anaerobic and (c) sequential anaerobic/aerobic conditions.

\section{5 Analyses}

An Agilent 1100 series liquid chromatography/mass spectrometry (LC/MSD) system (HP1100MSD; CA, USA) was used to analyze E2 and E1. For every beginning of the analysis, calibration was performed using 10 and $50 \mu \mathrm{gL}^{-1}$ of E2 and E1 standard solutions with a methanol content of $20 \%$ in v/v. Two internal standards (17 $\beta$-estradiol-C and estrone-C) were added to all samples in order to minimize measurement errors. Identification and quantification were thus made in negative SIM mode by following the well-used internal standard methodology. The target ions for E2 and E1 were 271 and 269. By adopting a higher injection volume ( $100 \mu \mathrm{L}$ for instance), the detection limit could reach a level of about $0.01 \mu \mathrm{gL}^{-1}$ for E2 and E1. In addition, the microbial densities were assessed using the indices of MLSS and MLVSS, for which glass fiber 
filters with a pore opening of $1.0 \mu \mathrm{m}$ were used to separate suspended solids from sludge liquors. The DOC was analyzed using a TOC analyzer (TOC-Vws, Shimadzu Co., Japan).

\section{$3 \quad$ Results and Discussion}

\subsection{Behavior of E2 and E1 when E2 was Spiked}

The behavior of E2 and E1 when E2 was spiked under aerobic, anaerobic and sequential anaerobic/aerobic conditions is illustrated in Figure 2. Under aerobic conditions, E2 decreased rapidly by up to $90 \%$ after $30 \mathrm{~min}$ and had totally disappeared after $2 \mathrm{~h}$. The results show that E1 and E2 are degraded completely in $8 \mathrm{~h}$ under aerobic conditions. This means that no estrogens remain in the effluent, because in practice the activated sludge process often has a HRT longer than 8 hours. This infers that all incoming estrogen will be degraded in the system.

Under anaerobic conditions, the amount of E2 degradation was approximately $68 \%$ of the initial E2 concentration after $2 \mathrm{~h}$ and then decreased by $82 \%$ after 8 h. Under sequential anaerobic/aerobic conditions, E2 decreased by $96 \%$ after 2 $\mathrm{h}$ and had totally disappeared after $3.5 \mathrm{~h}$. The decreasing concentration of E2 under aerobic conditions resembled that obtained in previous studies $[10,13,17,18]$ and under anaerobic conditions [14]. Following the concentration decrease of E2, its intermediate biodegradation product E1 emerged and apparent disappearance of E1 was found to occur after E2 had been nearly fully eliminated from the reactor. The transformation of E2 to E1 was also confirmed under aerobic and sequential anaerobic/aerobic conditions.

The maximum conversion of E2 to $\mathrm{E} 1$ was calculated using the equation $\left(\mathrm{C}_{\mathrm{E} 1 \max } / \mathrm{C}_{\mathrm{E} 20}\right) \times 100$, indicating that the maximum $\mathrm{E} 1$ concentration $\left(\mathrm{C}_{\mathrm{E} 1 \max }\right)$ was into initial E2 concentration $\left(\mathrm{C}_{\mathrm{E} 20}\right)$ [13]. The computed results are shown in Table 3. The highest maximum conversion of E2 to E1 (\%) was found to be $30.47 \%$ for the experiments under anaerobic conditions. However, the maximum conversion of E2 to E1 was not significantly different for aerobic, anaerobic and sequential anaerobic/aerobic conditions. 

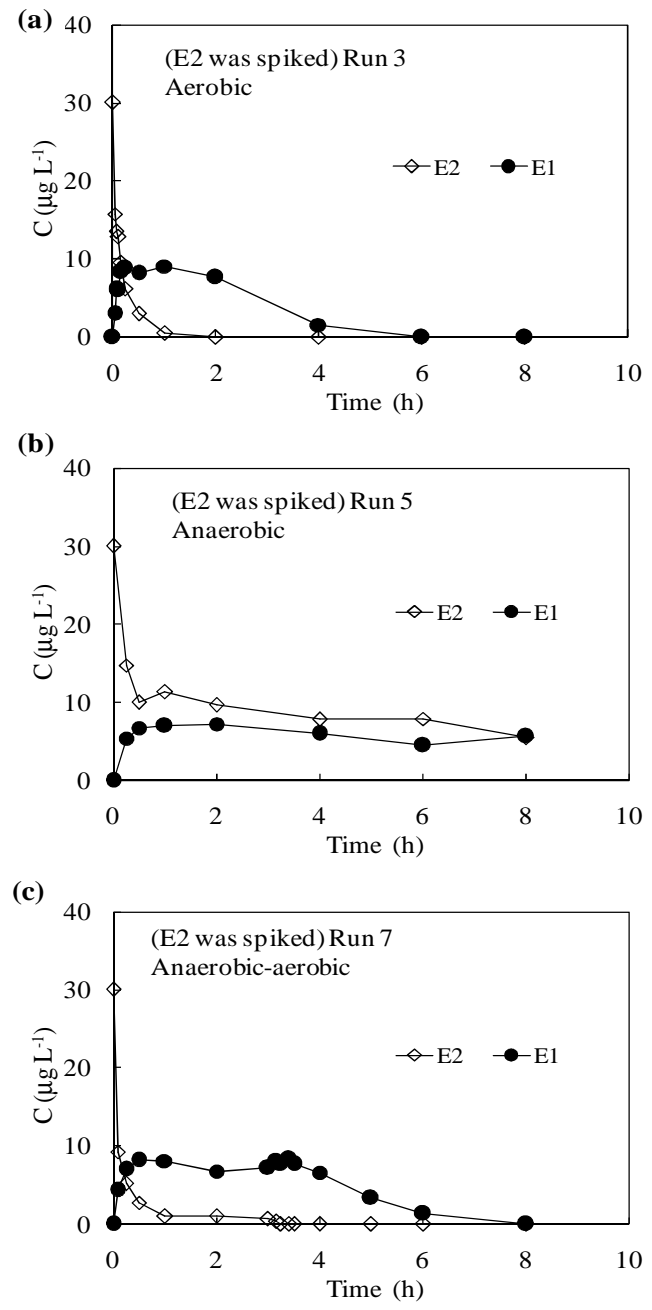

Figure 2 Profile concentrations of E2 and E1 when E2 was spiked.

Table 3 The apparent maximum conversion ratios of E2 and E1.

\begin{tabular}{|c|c|c|}
\hline \multicolumn{3}{|c|}{ Series I: Spiking of 17 $\beta$-estradiol (E2) } \\
\hline Conditions & Maximum conversion to E1 (\%) & Related Runs \\
\hline Aerobic & $29.08 \pm 1.45$ & Run 1 - Run 3 \\
\hline Anaerobic & $30.47 \pm 19.83$ & Run 4 - Run 6 \\
\hline Anaerobic $(3 \mathrm{~h})-$ aerobic $(5 \mathrm{~h})$ & $29.82 \pm 2.21$ & Run 7 - Run 9 \\
\hline \multicolumn{3}{|l|}{ Series II: Spiking of estrone (E1) } \\
\hline Aerobic & 0 & Run 10 - Run 12 \\
\hline Anaerobic & $28.27 \pm 6.58$ & Run 13 - Run 15 \\
\hline Anaerobic $(3 \mathrm{~h})-$ aerobic $(5 \mathrm{~h})$ & $12.30 \pm 2.94$ & Run 16 - Run 18 \\
\hline
\end{tabular}




\subsection{Behavior of E2 and E1 when E1 was Spiked}

The behavior of E2 and E1 when E1 was spiked under aerobic, anaerobic and sequential anaerobic/aerobic conditions is displayed in Figure 3. Compared to E2, the degradation of E1 was slower. Under aerobic conditions, E1 decreased by up to $70 \%$ and was no longer detected after $6 \mathrm{~h}$. No transformation of E1 to E2 was observed for the experimental run under aerobic conditions. In contrast, the transformation of E1 to E2 was confirmed under anaerobic and sequential anaerobic/aerobic conditions. Previous studies on the occurrence and behavior of estrogens in wastewater have suggested that where the concentration of E1 is concerned, the fraction originated from the conversion of E2 should not be neglected [19]. A recent study has shown that E1 is the most important natural endocrine-disrupting compound present in most natural water environments [16,20], and effective removal of E1 is probably the key to reducing the total estrogenicity in water environmental systems $[15,21]$ due to the following facts: (i) the load of E1 from STPs to receiving water bodies is about 10 times larger than E2, (ii) the estrogenic potency of E1 is weaker than that of E2 but is much stronger than nonylphenol and its precursors, and (iii) some conjugated species of E1 (for instance estrone-3-sulfate) may get disassociated after reaching the receiving water bodies.

The maximum conversion of E1 to E2 was also calculated using the equation $\left(\mathrm{C}_{\mathrm{E} 2 \max } / \mathrm{C}_{\mathrm{E} 10}\right) \times 100$, indicating that the maximum $\mathrm{E} 2$ concentration $\left(\mathrm{C}_{\mathrm{E} 2 \max }\right)$ was into initial $\mathrm{E} 1$ concentration $\left(\mathrm{C}_{\mathrm{E} 10}\right)$, as shown above in Table 3. The highest maximum conversion of E1 to E2 (\%) was found for the experimental runs under anaerobic conditions at $28.27 \%$. However, the maximum conversion of $\mathrm{E} 2$ to E1 was higher than the maximum conversion of E1 to E2.

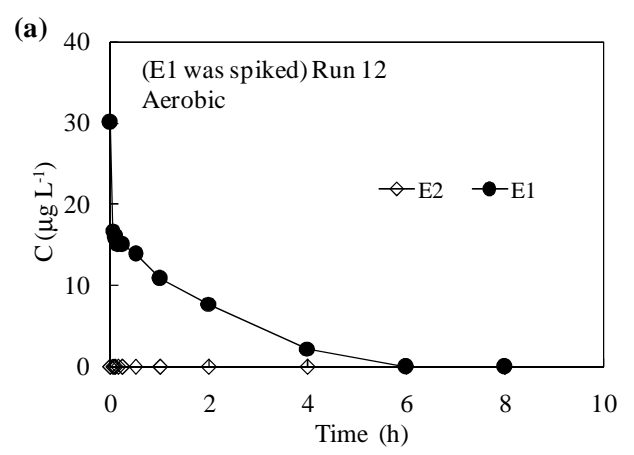

Figure 3 Profile concentrations of E2 and E1 when E1 was spiked. 
(b)

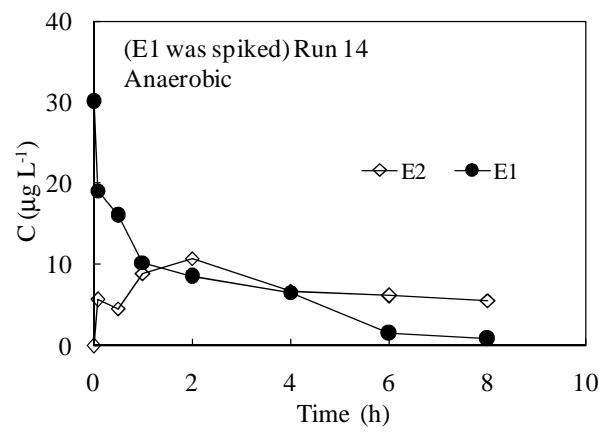

(c)

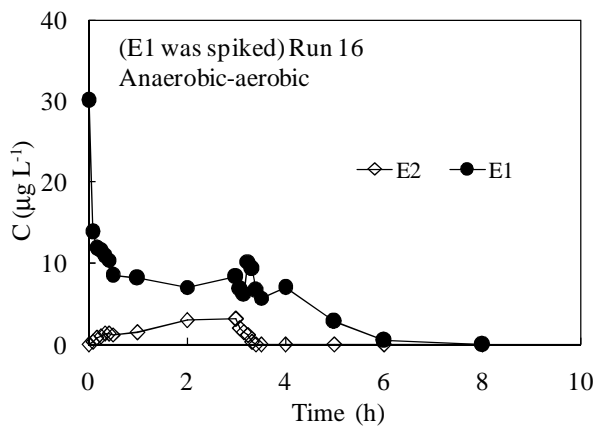

Figure 3 Continued. Profile concentrations of E2 and E1 when E1 was spiked.

\subsection{Degradation Rate Constant of E2 and E1}

The apparent degradation rates of E2 and E1 when spiked separately were generated assuming a first-order reaction calculated using Eq. (2). The estimated first-order degradation rate constants of E2 $\left(k_{\mathrm{E} 2}\right)$ and $\mathrm{E} 1\left(k_{\mathrm{E} 1}\right)$ examined under aerobic, anaerobic and sequential anaerobic/aerobic conditions are displayed in Table 4. The apparent first-order degradation rate constant of E2 $\left(k_{\mathrm{E} 2}\right)$ under aerobic conditions was twenty four times faster than that under anaerobic conditions. Compare to $k_{\mathrm{E} 2}$, the apparent first-order degradation rate constant of E1 $\left(k_{\mathrm{E} 1}\right)$ under aerobic conditions was about three times faster than that under anaerobic conditions. The $k_{\mathrm{E} 2}$ and $k_{\mathrm{E} 1}$ for the experimental runs under sequential anaerobic/aerobic conditions were calculated separately for each condition, as shown in Table 4.

Generally for all conditions, $k_{\mathrm{E} 1}$ is lower than $k_{\mathrm{E} 2}$, indicating that $\mathrm{E} 2$ disappeared from the reactors much faster than E1 and suggesting that E1 is probably more persistent than E2 in the effluent of sewage treatment plants. The slow disappearance of E1 is consistent with the investigation of activated sludge by 
Li et al. [12,13] and Urase and Kikuta [17]. In another study, Yu et al. [21] isolated 14 diverse E2-degrading bacteria from activated sludge of a wastewater treatment plant. They reported that all 14 isolates were capable of converting E2 to E1, but only 3 isolates showed the ability to degrade E1.

Table 4 The apparent first-order degradation of E2 and E1.

\begin{tabular}{lccc}
\hline \begin{tabular}{l} 
Series I: Spiking of 17 $\beta$-estradiol (E2) \\
\multicolumn{1}{c}{ Conditions }
\end{tabular} & $\mathbf{k}_{\mathbf{E 2}}\left(\mathbf{h}^{\mathbf{- 1}}\right)$ & $\mathbf{R}^{\mathbf{2}}$ & \multicolumn{1}{c}{ Related Runs } \\
\hline Aerobic & $2.92 \pm 0.86$ & $0.89-0.96$ & Run 1 - Run 3 \\
Anaerobic & $0.12 \pm 0.04$ & $0.83-0.88$ & Run 4 - Run 6 \\
Anaerobic (3 h) - aerobic (5 h) & & & \\
$\quad$ - Anaerobic & $0.46 \pm 0.31$ & $0.76-0.91$ & Run 7 - Run 9 \\
$\quad$ - Aerobic & $4.19 \pm 0.40$ & $0.91-0.99$ & \\
\hline Series II: Spiking of estrone (E1) & & & \\
\hline Aerobic & $1.15 \pm 0.38$ & $0.88-0.98$ & Run 10 - Run 12 \\
Anaerobic & $0.53 \pm 0.15$ & $0.96-0.99$ & Run 13 - Run 15 \\
Anaerobic (3 h) - aerobic (5 h) & & & \\
$\quad$ - Anaerobic & $0.25 \pm 0.08$ & $0.72-0.90$ & Run 16 - Run 18 \\
$\quad$ - Aerobic & $0.84 \pm 0.51$ & $0.85-0.99$ & \\
\hline
\end{tabular}

\section{Conclusions}

The behavior of $17 \beta$-estradiol (E2) and estrone (E1) was investigated using semicontinuous activated-sludge experiments under aerobic, anaerobic and sequential anaerobic/aerobic conditions. The results indicate that, initially, E2 and E1 decrease due to sorption onto activated sludge and then degrade through biodegradation. The highest maximum conversion rates of E2 to E1 and E1 to E2 were found under anaerobic conditions. Compare with E2, the maximum conversion of E2 to E1 (29.08-30.47\%) was higher than the maximum conversion of E1 to E2 (0-28.27\%). The degradation rate of E2 was much faster than that of E1 when both were spiked separately. The disappearance rates of E2 and E1 determined by assuming first-order reactions, fell in the ranges of $0.12-4.19 \mathrm{~h}^{-1}$ and $0.25-1.15 \mathrm{~h}^{-1}$, respectively. The results obtained in this research are important for better understanding the behavior of natural estrogens in sewage treatment plants (STPs) in order to determine efficient operation conditions for the removal of natural estrogens before release to the environmental system.

\section{Acknowledgements}

This work was supported in part by Grants-in-Aid for Scientific Research (Kiban-B, No. 17360261) from the Japan Society for the Promotion of Science (JSPS) and by the River Fund in charge of the Foundation of River and Watershed Environment Management (FOREM), Japan. Thanks go to the Directorate General of Higher Education (DIKTI) Indonesia, for its support 
through the Program Academic Recharging (PAR-C) 2011 at Gifu University Japan.

\section{References}

[1] Vos, J.G., Dybing, E., Greim, H.A., Ladefoged, O., Lambre, C., Tarazona, J.V., Brandt, I. \& Vethaak, A.D., Health Effects of EndocrineDisrupting Chemicals on Wildlife, with Special Reference to The European Situation, Critical Review, Toxicology, 30, pp. 71-133, 2000.

[2] Christiansen, L.B., Winther-Nielsen, M. \& Helweg, M.C., Feminization of Fish: The Effect of Estrogenic Compounds and Their Fate in Sewage Treatment Plants and Nature, Environmental Project No. 729, Danish Environmental Protection Agency, Denmark, 2002.

[3] Imai, S., Koyama, J. \& Fujii, K., Effects of $17 \beta$-estradiol on the Reproduction of Java-medaka (Oryzias javanicus), a New Test Fish Species, Marine Pollution Bulletin, 51, pp. 708-714, 2005

[4] Johnson, A.C., Belfroid, A. \& Di Corcia, A., Estimating Steroid Estrogens Inputs Into Activated Sludge Treatment Works and Observations on Their Removal from The Effluent, Science of The Total Environment, 256, pp. 163-173, 2000.

[5] Johnson, A.C. \& William, R.J., A Model to Estimate Influent and Effluent Concentrations of Estradiol, Estrone, And Ethinylestradiol At Sewage Treatment Works, Environmental Science and Technology, 38(13), pp. 3649-3658, 2004.

[6] Joss, A., Andersen, H., Ternes, T., Richle, P.R. \& Siegrist, H., Removal of Estrogens in Municipal Wastewater Treatment under Aerobic and Anaerobic Conditions: Consequences for Plant Optimization, Environmental Science and Technology, 38 (11), pp. 3047-3055, 2004.

[7] Servos, M.R., Bennie, D.T., Burnison, B.K., Jurkovic, A., McInnis, R., Neheli, T., Schnell, A., Seto, P., Smyth, S.A., \& Ternes, T.A., Distribution of Estrogens, 17 $\beta$-Estradiol and Estrone, in Canadian Municipal Wastewater Treatment Plants, Science of the Total Environment, 336, pp. 155-170, 2005.

[8] Isobe, T., Serizawa, S., Horiguchi, T., Shibata, Y., Managaki, S., Takada, H., Morita, M. \& Shiraishi, H., Horizontal Distribution of Steroid Estrogens in Surface Sediments in Tokyo Bay, Environmental Pollution, 144, pp. 632-638, 2006.

[9] Pojana, G., Gomiero, A. Jonkers, N. \& Marcomini, A., Natural and Synthetic Endocrine Disrupting Compounds (EDCS) in Water, Sediment and Biota of A Coastal Lagoon, Environment International, 43, pp. 929936, 2007. 
[10] Desmiarti, R. \& Li, F.S., Sorption and Degradation Capacity of Natural Estrogens in Freshwater Environmental System in Japan, ITB J. Eng. Sci., 43(2), pp. 153-160, 2011.

[11] Desmiarti, R., Li, J.F. \& Li, F.S., Behavior of Natural Estrogens in Reservoir: Investigations Based on Continuous Flow Experiments and Model Analysis, Water, Air, \& Soil Pollution, 223(6), pp. 3307-3320, 2012.

[12] Li, F.S., Yuasa, A., Obara, A. \& Matheuws, P.A., Aerobic Batch Degradation of 17 $\beta$-Estradiol (E2) by Activated Sludge: Effect of Spiking E2 Concentrations, MLVSS and Temperature, Water Research, 39, pp. 2065-2075, 2005.

[13] Li, F.S., Desmiarti, R., Yuasa, A. \& Horio, A., Behavior of Natural Estrogens in Semicontinuous Activated Sludge Biodegradation Reactors, Bioresource Technology, 99, pp. 2964-2971, 2008.

[14] Czajka, C.P. \& Londry, K.L., Anaerobic Biotransformation of Estrogens, Science of the Total Environment, 367, pp. 932-941, 2006.

[15] Auriol, M., Filali-Meknassi, Y., Tyagi, R.D., Adams, D.C. \& Surampalli, R.Y., Endocrine Disrupting Compounds Removal from Wastewater, A New Challenge, Process Biochemistry, 41(3), pp. 525-539, 2006.

[16] Ying, G-G., Toze, S., Hanna, J., Yu, X-Y., Dillon, P.J. \& Kookana, R.S., Decay of Endocrine-Disrupting Chemicals in Aerobic and Anoxic Groundwater, Water Research, 42, pp. 1133-1141, 2008.

[17] Urase. T. \& Kikuta. T., Separate Estimation of Adsorption and Degradation of Pharmaceutical Substances and Estrogens in The Activated Sludge Process, Water Research, 39, pp. 1289-1300, 2005.

[18] Ternes, T.A., Kreckel, P.J. \& Mueller, J., Behavior Occurrence of Estrogens in Municipal Sewage Treatment Plants-II: Aerobic Batch Experiment with Activated Sludge, Science of the Total Environment, 225, pp. 91-99, 1999.

[19] Esperanza, M., Suidan, M.T., Nishimura, F., Wang, Z.-M., Sorial, G.A. \& Zaffiro, A., Determination of Sex Hormones and Nonylphen Ethoxylates in The Aqueous Matrixes of Two Pilot-Scale Municipal Wastewater Treatment Plants, Environmental Science and Technology, 38, pp. 30283035, 2004.

[20] D’Ascenzo, G., Di Corcia, A., Gentili, A., Mancini, R., Mastropasqua, R., Nazzari, M. \& Samperi R., Fate of Natural Estrogen Conjugates in Municipal Sewage Transport and Treatment Facilities, Science of the Total Environment, 302, pp. 199-209, 2003.

[21] Yu, C-P., Roh, H. \& Chu, K-H., 17 $\beta$-Estradiol-Degrading Bacteria Isolated from Activated Sludge, Environmental Science and Technology, 41, pp. 486-492, 2007. 